\title{
A simple analysis of the tax gap Balkan region
}

\author{
Marsida Harremi \\ University "Fan S. Noli", Korce, Albania \\ Email: mharremi@yahoo.com
}

DOI:10.5901/mjss.2014.v5n19p365

\begin{abstract}
:
The main purpose of this study is the creation of a map of the division of the tax gap is to create an informative presentation and an overview of the phenomenon of tax policy. This analysis of the tax gap creates spaces for every interested party and to judge what brings consequences tax gap and what changes need to be made in the tax system a little bit to narrow this gap. One should note that any tax system throughout the world constantly facing the challenges of the tax gap as this is a negative phenomenon inherent in tax administration. A collaboration between policymakers and citizens would be the best solution and the most effective for reducing the tax gap. Creating a special mission in tax administration will serve as a model of good governance. Anyone who wants to contribute to maintaining the same level of tax gap or even worse attempt to increase his will help increase the tax burden on the taxpayers expenses honest. In this paper will be analyzed countries of the Balkan region. Discussion on the tax gap helps to focus attention on the events and lives of fiscal management that is a match with the culture face to face fiscal evasion and tax avoidance. This discussion should provide a light on the dilemma of tax administration, where efforts to promote voluntary compliance in the calculation and payment of taxes need to oppose strong measures to disarm those that do not apply the same principles of voluntary compliance. Tax gap can be assessed through two main models. The first model deals with microeconomic indicators approach or different model down - up. The second model which will apply and in this study has to do with the alignment of various macroeconomic indicators from top down. Adapting the second model we can measure and evaluate the VAT gap and excise tax gap. But this approach has its limitations, because it gives no explanation as to how the gap is present in different parts of the area measured. Another difficulty has to do with the fact the complexity of the tax system. In this case, it is difficult to measure the tax effects of activities that are not subject to the tax, or for activities that are part of the global exemption from VAT. Being careful in preparing data for tax gap map this study is based on data from the World Bank, HM Revenue, customs of each country included in the study, USAID and OECD.
\end{abstract}

Keywords: Estimate, Tax, Tax gap

\section{Introduction}

The global economic crisis has highlighted the continuing problem of tax evasion. For tax agencies to respond to a significant event prior requires knowing the extent of the problem. Each fiscal system worldwide phenomenon facing the tax gap. This negative phenomenon is almost unavoidable.

This study comprehensively examines recent research on the tax gap. We argue that the tax gap, as defined in conventional terms, is conceptually flawed because it fails to respond to the behavior of taxpayers adequately.

Tax gap is defined by many scholars fiscal expert in the field of scientific research but also scholars. In this paper we will describe the concept of the tax gap and by changing it from tax evasion.

Further study will continue with a description of the methodology used for measuring the tax gap. The methodology used in this study is based on macroeconomic indicators, but it should be noted that this approach has and its difficulties.

In the next section we introduce the tax gap analysis of the Balkan countries for fiscal year 2011-2012 as well as other macroeconomic indicators. What were the causes and consequences of creating this gap and has been its performance from one year to another.

And finally some important suggestions to students about reducing this gap which always falls more on the shoulders of citizens and businesses.

\section{What is the tax gap?}


There are several possible definitions regarding the tax gap. Most of these definitions were developed by the tax agencies that have managed to capture the difference between the amount of revenue from taxes and fees that should realistically be collected in case we would have a fair application of the rules of the income tax and factual were collected. Plumley (2005) states that the definition of the tax gap is divided into three components: failure to have a certain return, under-reporting of income and deductions also relevant exaggeration, failure to pay the full fee reported.

\subsection{Evasion, avoidance and quality of service the administration's tax}

A country's tax gap arises because of the failure to implement laws and lack of compliance of individual free will to implement these laws. If someone would come up voluntary implementation of fiscal laws (culture and information necessary) then there would be no tax gap. However, if tax evasion will rise, which in turn will bring an increase in the space between the implementation and non-implementation of the law, then the tax gap will widen.

In this way the tax gap grows proportionally the same size as tax evasion. By some estimates, the share of tax evasion in the tax gap goes 80 to $90 \%$.

First, the tax gap is highly related to tax evasion, but when we mention the term tax gap, this does not mean that we are talking simultaneously for tax evasion. Taimor to measure the gap is not so simple as to measure tax evasion. With tax evasion in this study is not meant paying taxes and not through the implementation of relevant legislation: a) filing false forms of income, whether income from business or individual, b) non-declaration and non-payment of part of the undisclosed liabilities, c) the silence of the high costs.

Secondly, the tax gap arises as a result of tax avoidance. With tax evasion in this paper will mean an attempt to reduce the obligations to be paid. This effort takes life by the use of legal gaps or irregularities tax incentives schemes, which do not violate the law but they serve their users to reduce the amount of current liability.

Third, the tax gap is associated with errors in the calculation of tax liabilities and tax culture of a country.

Fourth, the tax gap is also associated with poor quality of service tax administration. Tax gap is more prevalent where present corruption and bribery. All these elements bring an immense loss to the exact amount of duty payable.

\subsection{Defining the term "tax gap"}

Recently various fiscal authorities and organizations of various non-governmental organizations have studied the informal economy and the tax gap.

In different countries there are different definitions of clarity about the tax gap, but which have the same meaning. Elements of the tax gap in some publications are considered uncollectible as a lot of taxes and fees that are due to noncooperation and non-enforcement of relevant laws. Evolution of the tax gap does not take into account the fact of nonpayment of taxes and fees. Identify at what level the tax gap is going to make all parts of the tax revenues arising from activities being registered, the tax exemption schemes, the tax calculation errors, the errors arising from the selfassessments of tax declarations.

In the case of Albania, in the absence of an official definition and based on several studies that have been published by research organization, have reached a conclusion which can be regarded as appropriate in connection with the development objectives of the tax gap.

Tax gap is the difference between taxes and fees, to which must be regarded as payable to all citizens and businesses, and taxes that currently pay the taxpayers within a fiscal year and collected by the tax administration with its resources and tax agents.

\subsection{What is needed tax gap calculation?}

The discussion on tax gap helps to focus the attention on the events and lives of fiscal management that is a face match with the fiscal culture, the tax evasion and the tax avoidance. This discussion should provide guidance to the tax administration's dilemma, where efforts to promote voluntary compliance in the calculation and payment of taxes should to oppose strong measures to disarm those that do not apply the same principles of voluntary compliance. 
The tax gap helps to validate a trend for future fiscal policy and to support the fiscal debate for all concerned parties to set a clear dividing line between voluntary compliance and not, according to the needs of tax system to adapt for the level of the tax gap.

\section{Estimation methodology}

Tax gap can be calculated in several ways. One way is based on the level of voluntary compliance. Another approach is based on the type of tax and taxpayer groups. In the calculation that will appear in this paper we will refer to the gap based on macroeconomic model.

\subsection{The approach with macroeconomic indicators}

This methodology can be applied through the use of the different macro indicators that otherwise could be said a topdown approach (or indirectly). This approach can answers the main question how much taxes and fee should be paid in a certain area? These data derived from the relevance of the declarations and payments, and when compared with the appropriate level of taxes and fees, which must be declared and paid, than results in a difference that is the tax gap. This approach determines the absolute gap that must be filled by making all possible managerial and operational modifications oriented by the fiscal management policy. This approach determines the size of the area or of the activity that escapes taxation by providing the appropriate explanation or reasons why this happens.

But this approach has its limitations, because gives no explanation related to how the gap is present in different parts of the measured area. Another difficulty relates to the fact of the complicity of the tax system. On the other hand, macroeconomic data cannot identify the size of the area and taxes that escape taxation (i.e. tax gap cannot be identify if we have different types of the tax rate of VAT). In summary all as described this is the best way to summarize all activities and taxes, which left traces in national statistics due to their specifications.

\subsection{The approach with microeconomic data.}

Another approach to evaluate the tax gap is the bottom-up approach, where calculations are based on data from individuals or businesses. When is used these approach should be conducted surveys and the polls about the behavior of taxpayers, getting their answers relating to the tax gap for certain groups of activities and taxpayers. In this way there are included all data that result from the random tax audits, evasion cases audits and survey done from the administration for estimating the industries risks.

audits that performs tax administration have as the main objective identify and correcting the irregularities identified from tax books and reports of businesses from which they have estimated and have paid their taxes. Based on identification of the tax gap on certain activities and selected group of taxpayers the audit result is used as template to serve as guide note for all taxpayers for all the segments that include the taxpayers, and selected activities.

However, if the tax gap is the hidden tax and what is found to a taxpayer is a certain amount of the tax gap, then with extrapolating of results can be made the estimation for the entire segment where is part the taxpayer.

The tax gap according to tax audit, when compared with the approach according on macro data, so we can see what is actually the tax gap. For industries and taxpayers, which have been abject of several tax audits one can be considered that should be closer to the truth about the real tax gap than approach according to macro data. Otherwise can be accepted that the macro data approach is more closer to the reality of tax gap. An important point for surveys is the inclusion of a wider group of taxpayers to make as more as possible a realistic assessment of the tax gap. In surveys is likely to be included more data than can be accessed by tax administration by providing a more accurate assessment of total risk and the type of error made by the taxpayer. In these conditions, the possession of this information could make possible a more comprehensive assessment of multiple data. In the above description of the two approaches one can conclude clearly that what can't manages to fulfill one of approaches can be corrected by another approach, so we have beneficial interest in clarifying the real tax gap.

\section{4. "Tax Gap" Balkan region}


In the analysis for the Balkan region, for reasons linked with doubt mentality and sharing of the data and conclusions common is difficult to have an overall approval for the important topics, such as tax gap. Although different country may have other data from these that we have presented on this paper. This mean that there is no problem of calculation and of approach to the sources and information but happens to be underestimated or not to be used correctly, neither sources of information, but either data to assess realistically the phenomenon. Data on the overall tax rates in operation came from the European Union 2011 edition of 'Taxation trends in the European Union, table 1. This data tended to be lower than that reported by the Heritage Foundation and for reasons of prudence, and because this is a European Union report has been preferred as a result. Data on the overall tax rate and government spending as a proportion of GDP, used for some comparison purposes, came from the Heritage Foundation. Data on spending on healthcare as a proportion of GDP, again used for some comparison purposes, came from the World Health Organisation report 'World Health Statistics 2011', page 127 and following, all of which data has been checked by the WHO with national government. Exchange rate data for translation to local currencies when appropriate came from US Treasury data. Having assembled these various sources of data, the GDP of a state was multiplied by the size of the informal economy in percentage terms to estimate the value of that state's informal economy. This sum was then multiplied by the percentage overall tax burden of the state in question to estimate the total tax evaded in the state. It is stressed that much of the data used to prepare these calculations, whether it be GDP, population data and overall tax rates, is estimated: that is the nature of macroeconomic information. The resulting research findings are also, therefore, by definition estimates.

However, it is suggested that they are likely to be the best possible estimates and as such provide valuable insights into the scale of tax evasion and its likely impact on a country-by-country basis throughout the European Union. The size and development of informal economy is calculated with the MIMIC estimation procedure.

Presented in Table 1, are estimates of the informal economy and tax gap for the Balkan countries for 2011 fiscal year. Comparing the indicators of table 1 , one can see that:

Firstly, the data suggests that part of the economy, which is not part of the fiscal system constitutes one third of the GDP of the Balkans. This mean that 1 in 3 U.S. dollars circulating in the Balkans and are not included in the fiscal system and taxable. For 2011 fiscal year this ration is better in Greece (1 to 4) and Serbia (1 to 3.4). The ration is worse in Macedonia (1 to 2.7), Bulgaria (1 to 2.8), Kosovo and Montenegro (1 to 2.9). If compare with the global ration (1 to 6 ) and in Europe report (1 to 5), the Balkans shows that is far away from the formal economy of EU states and is close to the levels in Latin America (1 to 2.7) and Africa (1 to 2.9).

Secondly, comparing the indicators for the economy for fiscal year 2012 may see that:

Greece and Serbia are still in good position compared with other Balkan countries. We have an informal economy improvement regarding Romania Croatia and while we can not say the same for Montenegro and Macedonia. The economy continues to be their worst levels.

Thirdly, the data show that the informal economy in the Balkan countries, it is the same level at the extent of government spending budget Balkans, a share of 33\% of GDP for 2011 and $32.61 \%$ for 2012. This high level tells that tax evasion hidden in this high level of informality is a crime against the democracy in development, but also to society and its morality. This is a social illness that shatters economy that actually needs more funds than in previous periods of trouble moments of global crisis or the impact of global crises of other neighbor countries. The economy and citizens need to increase public services, but that do not take them because of the low level of fiscal contribution to the budget, but also that fact influence the behavior and tax burden of the compliant taxpayers. In similar conclusions can reach everybody if tend to compare statistics with each other.

Finally, it should be noted that some argue that reducing the tax gap during a period of austerity is an in appropriate course of action. Their argument is that all taxation reduces consumer demand in the economy and to therefore collect more tax at this time would reduce demand even more than is already happening and so increase the risk of recession in Europe.

This argument is partial, and false. Whilst it is true that reducing tax rates (in the process increasing a fiscal deficit) is a mechanism for stimulating an economy during a recession because such behaviour should increase effective consumer demand this is a policy that only works when a government deficit results and if it is within the legitimate economy, undertaken with a democratic mandate with the intention of delivering prosperity. Ignoring tax evasion is something very different indeed: that is turning a blind eye to criminality. That criminality does not increase demand, it reallocates the ability to consume from those who should enjoy it according to the democratic mandate (i.e. the government and those they wish to enjoy the benefit of their programmes of spending) to those who are willing to participate in criminal activity. If the 
government were to spend all the tax it could collect from tax evaders that government spending would stimulate demand just as much as the private consumption of tax evaders does: reallocating that consumption from those with legitimate right to undertake it to those without any such right does not change demand, it just changes those benefitting from the resulting consumption to ensure that those with legal and ethical right to that spending enjoy it and those who currently spend it as the proceeds of crime do not. To argue against tackling tax evasion on supposed economic grounds ignores this fact and ignores the importance of maintaining trust and the rule of law if an effective market economy is to be maintained. Any reasonable policy reaction to this data on the tax gap in the Balkan countries must focus on reducing the tax gap, and not eliminating it.

\section{Conclusion}

If compared the average tax gap of Balkans, then Albania is 3.4 percentage point higher. The tax gap with higher level in Balkan can be found in Macedonia for 2011 fiscal year and for 2012 the tax gap with higher level is in Montenegro. The tax gap with lower level can be found in Serbia.

Most of the taxes and fees that determine the tax system (see the scheme of tax gap) are declared and paid voluntarily. Another part of the paid late, but it is part of a voluntary payment as long as they are responsible for payment of interest and penalties related to liabilities that are paid late. But still some of the fees and taxes are not paid at all or that are part of the payment by implementing measures after tax audits and investigations. These revenues, including other revenues that can not be identified, to make up the lost tax revenue.

Tax gap is created by the series of behaviors of individuals and businesses, which are summarized:

- Negligence or no accountability in accounting estimates and occupancy taxes, and bad consequences as reflected in tax returns

- Lack of knowledge of legislation and obligations with respect to the law

- Conducting deliberate evasion, and the use of tax avoidance schemes for the purposes of reporting or not reporting

- Failure and unpaid obligations

These features also show how to access shared taxes lost. In calculating the gross gap is the gap theory that assesses fees to be paid. In calculating the net tax gap that is left undeclared, unreported and unpaid.

In this evaluation, the tax gap is influenced by the effects of national policy, but also by international law. For the first factor explained above how to influence the creation of the tax gap. Tax gap should be sought between the lack of budget money, derived from the constitutional obligation to pay income tax on the basis of the individuals or businesses with what everyone really pay, expressed as a burden tax. In this process there is a difference relation to the liability for taxes determined for every citizen and business and the collection of the amount due under the legislation in force. However, even if they could adhere to the legal framework for the closed network of "fiscal hole", there remains the possibility of tax evasion and informality, because of the many forms for concealment of income. It is important to distinguish between the tax gap regarding the definition and tax gap created by the tax administration model. In summary both of them, dealing with tax gap.

Having reviewed various studies on tax evasion and how it can help to measure tax revenues, Vaillancourt (2004) apply concludes: "The relationship between the gray and the percentage of income in accordance with ties to the income tax individual is not simple.

Additionally, tax compliance associated with other taxes also must be connected to the black economy, the answer is a little about a lot of poor, which reflects at least care about the use of size of the underground economy to measure the importance of hard - Income tax "(p.93). Finally, while this study has considered the measurement and the use of tax gap estimates, we shall leave it to others about this matter exactly how challenging it can be done elsewhere to reduce the tax gap (e.g. GAO, 2005, 2007, 2012).

\section{References}

Bloomquist, K. (2006). An overview of some recent IRS research on taxpayer compliance behavior. In Further Global Challenges in Tax Administration, M. McKerchar and M. Walpole, (Eds.) Birmingham, UK: Fiscal Publications. 
General Accounting Office (2012). Tax gap: Sources of noncompliance and strategies to reduce it. GAO-12-651T, Washington DC: GAO.

Mazur, M. \& Plumley, A. (2007). Understanding the tax gap. National Tax Journal 60, 569-576.

McManus, J., \& Warren, N. (2006). The case for measuring tax gap. e-Journal of Taxation Research 4 (1), 61-79.

Plumley, A. (2005). Preliminary update of the tax year 2001 individual income tax underreporting gap estimates. Paper Presented at the 2005 Internal Revenue Service Research Conference. Ëashington DC: IRS.

O'Higgins, M. (1989). Assessing the underground economy in the United Kingdom. In The underground economies: Tax evasion and information distortion, E. Feige (Ed.) Cambridge: Cambridge University Press.

Shadow Economies Around the World - Size, Causes, and Consequences, Friedrich Schneider and Dominic Este, 1999, Max-Planck-Institute for Research into Economic Systems

Shadow Economies and Corruption All Over the World: What Do We Really Know?, Friedrich Schneider, Institute for the Study of Labor, 2006, Johannes Kepler University of Linz and IZA Bonn

Vaillancourt, F. (2004). Measuring hard-to-tax income by tax compliance and national accounts information. In Taxing the hard-to tax: Lessons from theory and practice, J. Alm, J. Martinez-Vazquez, and S. Ëallace (Eds.), Amsterdam: Elsevier.

http://www.heritage.org

http://info.worldbank.org/governance/wgi/index.asp

www.instat.gov.al

www.minfin.gov.al

http://www.worldbank.org/en/country/albania

http://www.oecd-ilibrary.org/statistics

www.hmrc.gov.uk/statistics/tax-gaps/mtg-2013.pdf

http://ec.europa.eu/taxation_customs/resources/documents/taxation/tax_cooperation/combating_tax_fraud/reckon_report sep2009.pdf

http://en.wikipedia.org/wiki/List_of_countries_by_GDP_(nominal)

http://wwwwds.worldbank.org/external/default/WDSContentServer/WDSP/IB/2010/10/14/000158349_20101014160704/R

endered/INDEX/WPS5356.txt

http://www.heritage.org/index/Explore.aspx?view=by-variables

http://www.who.int/whosis/whostat/EN_WHS2011_Full.pdf

http://epp.eurostat.ec.europa.eu/cache/ITY_PUBLIC/2-26042011-AP/EN/2-26042011-AP-EN.PDF

http://www.taxjustice.net/cms/upload/pdf/AĀBA-TR-Code_long.pdf

http://www.ash.org.uk/files/documents/ASH_122.pdf

http://ec.europa.eu/taxation_customs/taxation/personal_tax/savings_tax/index_en.html

http://ec.europa.eu/taxation_customs/taxation/personal_tax/savings_tax/savings_directive_review/index_en.html

http://www.europolitics.info/hungarian-eu-presidency-fäils-to-convince-italy-art304314.html

http://www.taxresearch.org.uk/Documents/InfoEx0609.pdf

http://www.oecd.org/document/7/0,3746,en_2649_33767_38312839_1_1_1_1,00.html

http://www.taxresearch.org.uk/Documents/500000Final.pdf

http://www.taxresearch.org.uk/Documents/500000Final.pdf

http://www.economist.com/node/21543164

https://www.incorporateonline.co.uk/pack_default.cfm?gclid=CKOkhamSk64CFecmtAod7m6MKQ

http://www.taxresearch.org.uk/Documents/500000Final.pdf

Table 1. Estimation of informal economy and Tax Gap for the Balkan Countries, 2011 fiscal year. 


\begin{tabular}{|c|c|c|c|c|c|c|c|c|c|}
\hline Country & GDP & $\begin{array}{l}\text { Budget } \\
\text { expenditure } \\
\mathrm{S} \\
\text { / GDP }\end{array}$ & $\begin{array}{l}\text { Health } \\
\text { expenditure } \\
\mathrm{s} \\
\text { / GDP }\end{array}$ & $\begin{array}{l}\text { Size } \\
\text { Econ }\end{array}$ & $\begin{array}{l}\text { Informal } \\
\text { ny }\end{array}$ & $\begin{array}{l}\text { Tax } \\
\text { burde } \\
n\end{array}$ & $\begin{array}{l}\text { Tax gap } \\
\text { as a } \\
\text { proportio } \\
\mathrm{n} \text { of inf. } \\
\text { Econ. }\end{array}$ & $\begin{array}{l}\text { Budge } \\
\text { t exp.' } \\
\text { Tax } \\
\text { Gap }\end{array}$ & $\begin{array}{l}\text { Health } \\
\text { exp.' } \\
\text { Tax } \\
\text { Gap }\end{array}$ \\
\hline & $m \ln \$$ & $\%$ & $\%$ & $\%$ & $m \ln \$$ & $\%$ & $m \ln \$$ & $\%$ & $\%$ \\
\hline Albania & 12,959 & 28.6 & 6.8 & 33.4 & 4,328 & 23.1 & 1,000 & 27 & 113.5 \\
\hline $\begin{array}{l}\text { Bosnia- } \\
\text { Herzegovin } \\
\text { a }\end{array}$ & 18,088 & 50.3 & 10.3 & 33.6 & 6,078 & 41.2 & 2,504 & 27.5 & 110 \\
\hline Bulgaria & 53,514 & 35.2 & 7.1 & 35.3 & $\begin{array}{l}18,89 \\
0\end{array}$ & 34.4 & 6,498 & 34 & 171 \\
\hline Croatia & 61,789 & 40.6 & 7.8 & 32.1 & $\begin{array}{l}19,83 \\
4\end{array}$ & 26.6 & 5,276 & 79 & 109 \\
\hline Greece & $\begin{array}{l}298,73 \\
4\end{array}$ & 46.8 & 10.1 & 27.5 & $\begin{array}{l}82,15 \\
2\end{array}$ & 30 & 24,646 & 17.6 & 82 \\
\hline Kosovo & 6,446 & 31.9 & 2.1 & 35 & 2,256 & 23.1 & 521 & 25 & 383 \\
\hline Macedonia & 10,165 & 24.5 & 6.8 & 37.6 & 3,822 & 29.3 & 1,120 & 45 & 162 \\
\hline Montenegro & 4,550 & 41.7 & 9.1 & 35 & 1,593 & 28 & 446 & 23.5 & 108 \\
\hline Romania & $\begin{array}{l}179,79 \\
4\end{array}$ & 37.7 & 5.4 & 32.6 & $\begin{array}{l}58,61 \\
3\end{array}$ & 28.1 & 16,470 & 24.3 & 170 \\
\hline Serbia & 45,043 & 21.6 & 10.4 & 29.1 & $\begin{array}{l}13,10 \\
8\end{array}$ & 34.1 & 4,470 & 46 & 95 \\
\hline $\begin{array}{l}\text { Total/ } \\
\text { Average }\end{array}$ & $\begin{array}{l}691,08 \\
2\end{array}$ & 35.89 & 7.59 & $\begin{array}{l}33.1 \\
2\end{array}$ & $\begin{array}{l}21,06 \\
7\end{array}$ & 29.79 & 62,951 & 34.89 & $\begin{array}{l}150.3 \\
5\end{array}$ \\
\hline
\end{tabular}

Table 2. Estimation of informal economy and Tax Gap for the Balkan Countries, 2012 fiscal year.

\begin{tabular}{|c|c|c|c|c|c|c|c|c|c|}
\hline \multirow[t]{2}{*}{ Country } & GDP & $\begin{array}{l}\text { Budget } \\
\text { expenditure } \\
\mathrm{s} \\
\text { / GDP }\end{array}$ & $\begin{array}{l}\text { Health } \\
\text { expenditure } \\
\mathrm{s} \\
\text { / GDP }\end{array}$ & \multicolumn{2}{|c|}{$\begin{array}{l}\text { Size of Informal } \\
\text { Economy }\end{array}$} & $\begin{array}{l}\text { Tax } \\
\text { burde } \\
n\end{array}$ & $\begin{array}{l}\text { Tax gap } \\
\text { as a } \\
\text { proportio } \\
n \text { of inf. } \\
\text { Econ. }\end{array}$ & $\begin{array}{l}\text { Budge } \\
\text { t exp.' } \\
\text { Tax } \\
\text { Gap }\end{array}$ & $\begin{array}{l}\text { Health } \\
\text { exp.' } \\
\text { Tax } \\
\text { Gap }\end{array}$ \\
\hline & $m \ln \$$ & $\%$ & $\%$ & $\%$ & $m \ln \$$ & $\%$ & $m \ln \$$ & $\%$ & $\%$ \\
\hline Albania & 12,648 & 32.3 & 6 & 34 & 4,300 & 24.3 & 1,045 & 26 & 159 \\
\hline
\end{tabular}




\begin{tabular}{|c|c|c|c|c|c|c|c|c|c|}
\hline $\begin{array}{l}\text { Bosnia- } \\
\text { Herzegovin } \\
\text { a }\end{array}$ & 17,465 & 50.3 & 9.9 & 34 & 5,938 & 37.6 & 2,233 & 25 & 127 \\
\hline Bulgaria & 50,972 & 37.3 & 7.4 & 31.9 & $\begin{array}{l}19,93 \\
0\end{array}$ & 33.3 & 6,637 & 35 & 176 \\
\hline Croatia & 59,228 & 40.7 & 6.8 & 29 & $\begin{array}{l}17,17 \\
6\end{array}$ & 23.3 & 4,002 & 17 & 99.4 \\
\hline Greece & $\begin{array}{l}248,93 \\
8\end{array}$ & 46.8 & 9.3 & 24 & $\begin{array}{l}59,74 \\
5\end{array}$ & 35.1 & 20,971 & 18 & 90.6 \\
\hline Kosovo & 6,445 & 31.9 & 2 & 36 & 2,320 & 23.1 & 536 & 26 & 415.5 \\
\hline Macedonia & 9,612 & 34.5 & 7.1 & 40.4 & 3,883 & 30 & 1,165 & 35 & 170.7 \\
\hline Montenegro & 4,376 & 48.8 & 7.6 & 41.5 & 1,816 & 30 & 545 & 25.5 & 163.7 \\
\hline Romania & $\begin{array}{l}169,38 \\
4\end{array}$ & 37.6 & 5.1 & 29.1 & $\begin{array}{l}49,29 \\
1\end{array}$ & 28.5 & 14,048 & 22 & 109 \\
\hline Serbia & 37,489 & 21.44 & 10.5 & 26.2 & 9,822 & 36.3 & 3,565 & 44 & 90.6 \\
\hline $\begin{array}{l}\text { Total/ } \\
\text { Average }\end{array}$ & $\begin{array}{l}616,55 \\
7\end{array}$ & 38.164 & 7.17 & $\begin{array}{l}32.6 \\
1\end{array}$ & $\begin{array}{l}17,42 \\
2\end{array}$ & 30.15 & 54,747 & 27.35 & $\begin{array}{l}160.1 \\
5\end{array}$ \\
\hline
\end{tabular}

Figure 1. Scheme of Tax Gap

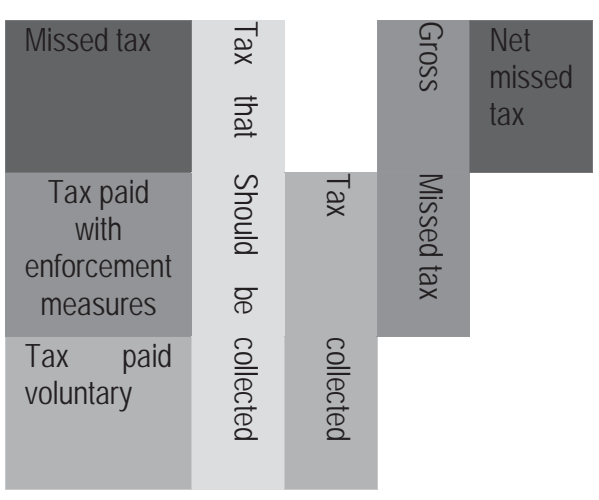

